\title{
Karakteristik Kuantitatif Sapi Bali dan Sapi Simbal (Simmental X Bali) di Kecamatan Renah Pamenang Kabupaten Merangin
}

\section{Quantitative characteristics of Bali cattle and the Simbal cattle in the Renah Pamenang Sub-district, Merangin District}

\section{Husni Almakmum, Depison*dan Helmi Ediyanto}

Program Studi Peternakan Fakultas Peternakan Universitas Jambi

Jl. Jambi-Ma. Bulian KM 15 Mendalo Indah Jambi 36361 Indonesia

Article history

Received: Aug 01, 2020;

Accepted: Feb 23, 2021

* Corresponding author:

E-mail:

depison.nasution@yahoo.com

DOI:

10.46549/jipvet.v11i1.132

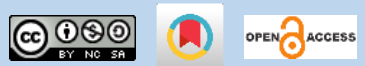

Abstract

This study aimed to determine the quantitative characteristics, the determinant of body size and shape, and the correlation of body measurements and the bodyweight of Bali and Simbal cattle in Renah Pamenang, Merangin District. The survey method was used along with purposive sampling, the samples were Bali and Simbal cattle aged I1 (Incicivus 1) and not in pregnant condition, with 60 cattle consisting of 30 males and 30 females. Observed data included: body weight, body weight gain, body length, shoulder height, chest circumference, chest weight, chest width, hip height, and canon circumference were analyzed using the t-test method. The principal component analysis was used to determine the determinant of size and shape of Bali and Simbal cattle followed by the regression and correlation analysis to determine the relationship and closeness of the relationship between body measurements with body weight. The result showed that the body weight, body weight gain, and body size of Bali cattle were significantly different $(\mathrm{P}<0.05)$ from Simbal. The body weight, body weight gain, and body size of Bali cattle were lower than Simbal cattle. The main characteristic of size in Bali and Simbal cattle was the Chest Circumference. The dominant characteristic of shape in Bali and Simbal cattle was shoulder height. The highest correlation between body measurements and body weight in Bali and Simbal cattle was the chest circumference.

Keywords: Quantitative characteristics; Bali cattle; Simbal cattle.

\section{Abstrak}

Penelitian ini bertujuan untuk mengetahui karakteristik kuantitatif, penciri ukuran dan bentuk tubuh, serta korelasi ukuran-ukuran tubuh dengan bobot badan sapi Bali dan Simbal di Kecamatan Renah Pamenang Kabupaten Merangin. Metode yang digunakan adalah survey dengan pengambilan sampel secara purposive sampling, yaitu sapi Bali dan Simbal, umur $\mathrm{I}_{1}$ (Incicivus 1), dan tidak dalam keadaan bunting sebanyak 60 sampel yang terdiri dari 30 ekor jantan dan 30 ekor betina pada masing-masing bangsa. Data yang dihimpun meliputi : bobot badan, pertambahan bobot badan, panjang badan, tinggi pundak, lingkar dada, dalam dada, lebar dada, tinggi pinggul dan lingkar kanon dianalisis menggunakan uji-t. Analisis komponen utama digunakan untuk mengetahui penciri ukuran dan bentuk tubuh sapi Bali dan Simbal kemudian dilanjutkan analisis regresi dan korelasi untuk mengetahui hubungan dan keeratan hubungan antara ukuranukuran tubuh dengan bobot badan. Hasil penelitian menunjukkan bahwa bobot badan, pertambahan bobot badan dan ukuran-ukuran tubuh sapi Bali berbeda nyata $(\mathrm{P}<0,05)$ dengan Simbal. Bobot badan, pertambahan bobot badan dan ukuran-ukuran tubuh sapi Bali lebih rendah dibandingkan Simbal. Penciri ukuran pada sapi Bali dan Simbal adalah lingkar dada. penciri bentuk pada sapi Bali dan 
Simbal adalah tinggi pundak. Korelasi tertinggi antara ukuran-ukuran tubuh dengan bobot badan sapi Bali dan Simbal adalah lingkar dada.

Kata kunci: Karakteristik kuantitatif; Sapi bali; Sapi sambal.

\section{PENDAHULUAN}

Indonesia merupakan salah satu negara yang memiliki banyak keanekaragaman ternak diantaranya adalah sapi Bali. Sapi Bali memiliki potensi cukup besar untuk dikembangkan sebagai sapi potong (Baaka et al., 2009). Sapi ini harus dijaga kelestariannya karena memiliki keunggulan komparatif dibanding ternak lainnya. Sapi Bali mampu beradaptasi di berbagai lingkungan pemeliharaan, serta memperlihatkan kemampuan untuk berkembang biak. Daya adaptasi yang sangat tinggi terhadap lingkungan ditunjukan dengan kemampuan memanfaatkan pakan yang berkualitas rendah, tetapi fertilitas dan conception rate yang baik (Rachma et al., 2011). Lebih lanjut dijelaskan bahwa sapi Bali memiliki tingkat pertumbuhan yang rendah di banding sapi-sapi Bos taurus.

Produktivitas sapi Bali dapat ditingkatkan melalui seleksi atau persilangan. Pemerintah provinsi Jambi melakukan dua kebijakan untuk memacu produksi sapi Bali, yaitu melalui seleksi dan juga melakukan persilangan antara indukan sapi Bali dengan beberapa bangsa pejantan. Diantara bangsa pejantan yang digunakan adalah sapi Simental yang merupakan salah satu sapi Bos taurus dengan kerangka tubuh yang besar. Sapi Simmental memiliki tingkat pertumbuhan yang tinggi (Khairi, 2016). Simbal merupakan anak hasil persilangan antara indukan sapi Bali dan pejantan sapi Simmental (Depison, 2010).

Sapi Bali dan sapi hasil persilangan antara Simmental dan Bali (Simbal) sudah cukup lama dikembangkan di provinsi Jambi diantaranya kabupaten Merangin. Salah satu kecamatan terpadat populasi sapi Bali dan Simbal adalah kecamatan Renah Pamenang. Namun informasi tentang tingkat produktivitas kedua bangsa sapi ini belum banyak diketahui. Upaya yang saat ini dilakukan yaitu melalui identifikasi lanjut tingkat produktivitas kedua bangsa sapi ini, salah satunya dengan karakterisasi kuantitatif yang bersifat ekonomis.
Karakteristik kuantitatif merupakan karakteristik yang tidak dapat diklasifikasikan dan dikontrol oleh banyak pasang gen yang bersifat aditif. Karakteristik kuantitatif dapat dilihat dari performan ternak yang digambarkan melalui : Bobot Badan (BB), Pertambahan Bobot Badan (PBB), Panjang Badan (PB), Tinggi Pundak (TP), Lingkar Dada (LD), Dalam Dada (DaD), Lebar Dada (LeD), Tinggi Pinggul (TPi), Lingkar Kanon (LK), (Hartati et al., 2010). Ukuran-ukuran tubuh memiliki hubungan timbal balik terhadap bobot badan. Pertambahan bobot badan biasanya diikuti oleh meningkatnya ukuran-ukuran tubuh. (Putra et $a l .$, 2014).

Berdasarkan uraian di atas, maka perlu dilakukan penelitian tentang karakteristik kuantitatif sapi Bali dan sapi Simbal di Kecamatan Renah Pamenang kabupaten Merangin. Penelitian ini bertujuan untuk mengetahui karakteristik kuantitatif, penciri ukuran dan bentuk tubuh serta hubungan ukuran-ukuran tubuh dengan bobot badan sapi Bali dan sapi Simbal yang akan dijadikan sebagai acuan dalam program seleksi dan pengembangan plasma nutfah sapi di masa yang akan datang.

\section{MATERI DAN METODE}

\section{MATERI}

Materi yang digunakan adalah sapi Bali dan sapi Simbal dengan jumlah 120 ekor yang terdiri dari 60 ekor ternak sapi Bali (30 ekor jantan dan 30 ekor betina) dan 60 ekor ternak sapi Simbal (30 ekor jantan dan 30 ekor betina). Peralatan yang digunakan adalah perlengkapan tulis, timbangan digital ketelitian $0,1 \mathrm{~kg}$, tongkat ukur, pita ukur, timbangan digital dan kamera digital.

\section{METODE}

Penelitian ini menggunakan metode survey dengan teknik pengambilan sampel secara purposive sampling. Umur ternak yang diambil adalah $\mathrm{I}_{1}$ (12-24 bulan), tidak dalam keadaan bunting. Data yang dihimpun meliputi: Bobot 
Badan (BB), Pertambahan Bobot Badan (PBB), Tinggi Pundak (TP), Panjang Badan (PB), Lingkar Dada (LD), Dalam Dada (DaD), Lebar Dada (LeD), Tinggi Pinggul (TPi) dan Lingkar Kanon (LK).

\section{ANALISIS DATA}

Data yang telah dikumpulkan dikelompokkan berdasarkan jenis kelamin

$$
t=\frac{\overline{\mathrm{x}}_{1}-\overline{\mathrm{x}}_{2}}{\sqrt{\frac{\sum\left(X_{j 1}-\overline{\mathrm{x}}_{1}\right)^{2}}{n_{1\left(n_{1}-1\right)}}+\frac{\sum\left(X_{j 2}-\overline{\mathrm{x}}_{2}\right)^{2}}{n_{2\left(n_{2}-1\right)}}}}
$$

Keterangan:

$t=$ nilai $\mathrm{t}$ hitung

$\overline{\mathrm{x}}_{1}=$ rataan sampel pada kelompok pertama

$\overline{\mathrm{x}}_{2}=$ rataan sampel pada kelompok kedua

$X_{j 1}=$ nilai pengamatan ke-j pada kelompok pertama

$X_{j 2}=$ nilai pengamatan ke-j pada kelompok Kedua

$n_{1}=$ jumlah sampel pada kelompok pertama, dan

$n_{2}=$ jumlah sampel pada kelompok kedua jantan dan betina serta hasil koreksi betina ke jantan pada sapi Bali dan sapi Simbal. Perbedaan BB, PBB, PB, TP, LD, DaD, LeD, LK, TPi antara jantan sapi Bali dan sapi Simbal jantan dan betina serta hasil koreksi betina ke jantan dianalisis dengan menggunakan uji $t$ (Gaspersz, 2006) dengan rumus sebagai berikut;

AKU adalah teknik statistik yang digunakan untuk mengetahui faktor penentu ukuran dan bentuk. Persamaan ukuran dan

bentuk diturunkan dari matriks kovarian. Model matematika yang digunakan untuk analisis ini (Gaspersz, 2006) sebagai berikut:

$$
Y_{j}=a_{1 j} X_{1}+a_{2 j} X_{2}+a_{3 j} X_{3}+\cdots+a_{7 j} X_{7}
$$

Keterangan:

$Y_{j} \quad=$ =komponen utama ke-j $(\mathrm{j}=1,2 ; 1=$ ukuran, $2=$ bentuk $)$

$X_{1,2,3, \ldots}=$ peubah ke $1,2,3, \ldots, 7$

$a_{1 j, 1 j, 1 j, \ldots}=$ vector eigen variable ke i $(1,2,3, \ldots, 7)$ dan komponen ke-j

Analisis Regresi merupakan analisis untuk melihat hubungan antara ukuran-ukuran tubuh dengan bobot badan. Model Regresi menurut

$$
Y=b_{0}+b_{1} X_{1}+b_{2} X_{2}+b_{3} X_{3}+\cdots+b_{19} X_{19}
$$

Analisis korelasi digunakan untuk menghitung korelasi menurut Alhamda (2016) mengetahui keeratan hubungan antara ukuranukuran tubuh dengan bobot badan. Rumus

$$
r_{x y}=\frac{n \sum x_{i} y_{i}-\left(\sum x_{i}\right)\left(\sum x_{i}\right)}{\sqrt{\left\{n \sum x_{1}^{2}-\left(\sum x_{1}\right)^{2}\right\}}\left\{n \sum y_{1}^{2}-\left(\sum y_{1}\right)^{2}\right\}}
$$

Keterangan: sebagai berikut:

$r_{x y}=$ Korelasi Pearson

$\mathrm{x}=$ ukuran-ukuran tubuh

$\mathrm{y}=$ bobot badan 
Pengolahan data dibantu dengan menggunakan perangkat lunak statistika yaitu Minitab versi 18.

\section{HASIL DAN PEMBAHASAN}

BOBOT BADAN DAN PERTAMBAHAN BOBOT BADAN SAPI BALI DAN SAPI SIMBAL

Rata-rata bobot badan dan pertambahan bobot badan harian sapi Bali dan sapi Simbal di Kecamatan Renah Pamenang dapat dilihat pada Tabel 1.

Tabel 1. Rata-rata bobot badan dan pertambahan bobot badan sapi Bali dan sapi Simbal.

\begin{tabular}{ccc}
\hline \multirow{2}{*}{ Uraian } & \multicolumn{2}{c}{ Bangsa } \\
\cline { 2 - 3 } & Sapi Bali & Sapi Simbal \\
\hline Bobot Badan (BB) & & $365,12 \pm 29,85^{\mathrm{b}}$ \\
$-\quad$ Jantan (kg) & $205,92 \pm 31,47^{\mathrm{a}}$ & $340,57 \pm 35,78^{\mathrm{b}}$ \\
$-\quad$ Betina (kg) & $180,27 \pm 15,52^{\mathrm{a}}$ & $365,12 \pm 38,37^{\mathrm{b}}$ \\
\hline$\quad$ Koreksi (kg) & $205,92 \pm 17,68^{\mathrm{a}}$ & $0,511 \pm 0,049^{\mathrm{b}}$ \\
\hline Pertambahan Bobot Badan (PBB) & & $0,428 \pm 0,079^{\mathrm{b}}$ \\
$-\quad$ Jantan (kg/ ekor/ hari) & $0,251 \pm 0,032^{\mathrm{a}}$ & $0,511 \pm 0,095^{\mathrm{b}}$ \\
\hline
\end{tabular}

Keterangan: Huruf yang berbeda pada baris yang sama berbeda nyata $(\mathrm{P}<0,05)$

Tabel 1. menunjukkan bahwa rata-rata bobot badan jantan dan betina sapi Bali lebih rendah jika dibandingkan dengan hasil penelitian Hikmawaty et al. (2014) bobot badan sapi Bali jantan dan betina di BPTU Pulukan Bali secara berturut adalah $210 \pm 10,7$ $\mathrm{kg}$ dan $207,89 \pm 7,02$. Hal yang sama juga dengan rata-rata bobot badan sapi Simbal betina lebih rendah dibandingkan hasil penelitian Kocu et al. (2019) yang mencatat rata-rata bobot badan sapi Simbal betina di kabupaten Keerom Papua adalah $389 \pm$ 44,98 kg. Rendahnya bobot badan sapi Bali dan sapi Simbal pada penelitian ini diduga karena adanya perbedaan lingkungan dan genetik dengan lokasi penelitian lainnya. Menurut Hartati et al. (2010) bahwa perbedaan bobot badan ternak sapi antar daerah kemungkinan disebabkan oleh berbagai faktor antara lain lingkungan dan genetik.

Hasil analisis statistik uji beda rata-rata bobot badan dan pertambahan bobot badan sapi Bali jantan, betina serta koreksi betina ke jantan berbeda nyata $(\mathrm{P}<0,05)$ dengan sapi Simbal. Perbedaan ini diduga karena bangsa sapi Simbal memiliki postur tubuh yang lebih besar dibandingkan bangsa sapi Bali. Hal ini sesuai dengan pendapat Kocu et al. (2019) bahwa perbedaan bobot badan antara sapi Bali dan sapi Simbal disebabkan karena sapi persilangan Simmental-Bali merupakan ternak dengan ukuran kerangka besar sedangkan sapi bali merupakan ternak dengan ukuran kerangka kecil. Perbedaan bangsa ternak akan berpengaruh terhadap produksi daging sapi (Setiyono et al., 2017). Pertambahan bobot badan yang berbeda antara sapi Bali dan sapi Simbal dikarenakan Sapi Bali memiliki pertumbuhan relatif lebih lambat daripada sapi hasil persilangan Simmental dan Bali (Simbal) (Syaiful et al., 2020). Menurut Depison (2010), bahwa Bobot badan anak hasil persilangan antara sapi Bali dan pejantan Simmental lebih tinggi daripada anak hasil persilangan sapi Bali dengan pejantan PO, Brahman dan Limousin.

Bobot badan dan pertambahan bobot badan jantan juga berbeda nyata $(\mathrm{P}<0,05)$ dengan betina baik pada sapi Bali maupun sapi Simbal. Perbedaan ini diduga karena adanya hormon androgen yang memicu pertumbuhan pada ternak jantan. Hal ini didukung oleh pendapat Hamdani et al. (2017) yang menyatakan kelenjar adrenal, sel-sel interstitial, serta salah satu dari steroid menghasilkan suatu hormon kelamin yang disebut androgen, dimana berperan sebagai pengatur stimula pertumbuhan sehingga terjadi pertumbuhan yang lebih baik pada sapi jantan. 


\section{UKURAN-UKURAN TUBUH SAPI BALI DAN SAPI SIMBAL}

Rataan ukuran-ukuran tubuh sapi Bali dan sapi Simbal di Kecamatan Renah Pamenang Kabupaten Merangin dapat dilihat pada Tabel 2. Hasil analisis uji beda rata-rata ukuranukuran tubuh menunjukkan bahwa sapi Bali jantan, betina serta koreksi betina ke jantan berbeda nyata $(\mathrm{P}<0,05)$ dengan sapi Simbal. Menurut Gunawan et al. (2008) bahwa salah satu faktor yang mempengaruhi perbedaan ukuran-ukuran tubuh adalah faktor genetik. Ditambahkan oleh Hikmawaty et al. (2014) bahwa perbedaan keragaman antar suatu ternak dapat menyebabkan perbedaan ukuran-ukuran tubuh, hal ini dapat dipengaruhi oleh faktor genetik dan penerapan teknik perkawinan, dimana teknik perkawinan yang diterapkan pada sapi Bali di kecamatan Renah Pamenang adalah perkawinan alam sedangkan pada sapi Simbal yaitu melalui teknik inseminasi buatan.

Tabel 2. Ukuran-ukuran tubuh sapi Bali dan sapi Simbal di Kecamatan Renah Pamenang

\begin{tabular}{ccc}
\hline \multicolumn{1}{c}{ Ukuran tubuh } & \multicolumn{2}{c}{ Bangsa } \\
\cline { 2 - 3 } Panjang Badan (PB), cm & Bali & Simbal \\
- Jantan & $113,27 \pm 3,80^{\mathrm{a}}$ & $134,40 \pm 6,50^{\mathrm{b}}$ \\
- Betina & $104,73 \pm 1,96^{\mathrm{a}}$ & $129,03 \pm 7,93^{\mathrm{b}}$ \\
- Koreksi & $113,27 \pm 2,12^{\mathrm{a}}$ & $134,40 \pm 8,26^{\mathrm{b}}$ \\
\hline Tinggi Pundak (TP), cm & - & \\
- Jantan & $104,73 \pm 3,59^{\mathrm{a}}$ & $124,93 \pm 4,85^{\mathrm{b}}$ \\
- Betina & $103,03 \pm 2,38^{\mathrm{a}}$ & $120,77 \pm 4,57^{\mathrm{b}}$ \\
- Koreksi & $104.73 \pm 2,42^{\mathrm{a}}$ & $124,93 \pm 4,73^{\mathrm{b}}$ \\
\hline Lingkar Dada (LD), cm & & \\
- Jantan & $140,80 \pm 5,65^{\mathrm{a}}$ & $160,37 \pm 7,28^{\mathrm{b}}$ \\
- Betina & $129,15 \pm 3,47^{\mathrm{a}}$ & $157,30 \pm 6,46^{\mathrm{b}}$ \\
- Koreksi & $140,80 \pm 3,78^{\mathrm{a}}$ & $160,37 \pm 6,59^{\mathrm{b}}$ \\
\hline Dalam Dada (DaD), cm & & \\
- Jantan & $45,68 \pm 3,95^{\mathrm{a}}$ & $50,98 \pm 3,66^{\mathrm{b}}$ \\
- Betina & $43,49 \pm 1,72^{\mathrm{a}}$ & $47,90 \pm 3,66^{\mathrm{b}}$ \\
- Koreksi & $45,68 \pm 1,81^{\mathrm{a}}$ & $50,98 \pm 3,90^{\mathrm{b}}$ \\
\hline Lebar Dada (LeD), cm & \\
- Jantan & $33,33 \pm 1,69^{\mathrm{a}}$ & $43,70 \pm 3,94^{\mathrm{b}}$ \\
- Betina & $30,27 \pm 1,41^{\mathrm{a}}$ & $39,89 \pm 2,39^{\mathrm{b}}$ \\
- Koreksi & $33,33 \pm 1,56^{\mathrm{a}}$ & $43,70 \pm 2,62^{\mathrm{b}}$ \\
\hline Tinggi Pinggul (Tpi), cm & & \\
- Jantan & $110,10 \pm 4,34^{\mathrm{a}}$ & $128,98 \pm 4,21^{\mathrm{b}}$ \\
- Betina & $105,90 \pm 2,70^{\mathrm{a}}$ & $125,88 \pm 4,62^{\mathrm{b}}$ \\
- Koreksi & $110,10 \pm 2,80^{\mathrm{a}}$ & $128,98 \pm 4,74^{\mathrm{b}}$ \\
\hline Lingkar Kanon (LK), cm & & $19,53 \pm 0,94^{\mathrm{b}}$ \\
- Jantan & $14,20 \pm 0,62^{\mathrm{a}}$ & $18,18 \pm 1,32^{\mathrm{b}}$ \\
- Betina & $13,50 \pm 0,44^{\mathrm{a}}$ & \\
\hline
\end{tabular}

Keterangan: Huruf yang berbeda pada baris yang sama berbeda nyata $(\mathrm{P}<0,05)$

Rendahnya ukuran-ukuran tubuh sapi Bali dibandingkan sapi Simbal diduga karena sapi Simbal merupakan turunan dari pejantan Simental yang merupakan salah satu sapi Bos taurus dengan pertumbuhan yang cepat. Susanti et al. (2015) yang menyatakan bahwa Pejantan Simmental memiliki peran cukup besar untuk pertumbuhan anak hasil persilangannya. Depison (2010), Perbaikan mutu genetik dapat dilakukan melalui persilangan diantaranya persilangan antara induk Bali dengan pejantan Simmental. Menurut Syaiful et al. (2020) bahwa sapi hasil persilangan Simmental dan Bali (Simbal) memiliki ukuran tubuh lebih baik dari pada sapi Bali di Luhan Nan Duo Kabupaten Pasaman Barat. 
Hasil analisis uji beda rata-rata menunjukkan ukuran-ukuran tubuh sapi jantan berbeda nyata $(\mathrm{P}<0,05)$ dengan sapi betina baik pada sapi Bali maupun sapi Simbal. Hal ini disebabkan oleh perbedaan laju pertumbuhan antara sapi jantan dan betina. Menurut Hamdani et al (2017) bahwa sapi jantan memiliki laju pertumbuhan yang lebih cepat dibandingkan sapi betina. pertumbuhan yang lebih cepat terjadi pada ternak jantan disebabkan oleh hormon steroid berupa hormon testosterone yang dihasilkan oleh testis (Setiyono, 2017). Salah satu faktor yang menyebabkan perbedaan kecepatan pertumbuhan baik pada sapi jantan maupun betina adalah fungsi pakan, dimana pakan yang dikonsumsi oleh sapi jantan mengarah untuk produksi daging sedangkan sapi betina cenderung untuk tujuan reproduksi (Socheh et al, 2018).

\section{PENCIRI UKURAN DAN BENTUK SAPI BALI DAN SAPI SIMBAL}

Analisis komponen utama penciri ukuran, penciri bentuk, keragaman total, dan nilai eigen ternak sapi Bali dan sapi Simbal disajikan pada Tabel 3. Berdasarkan Tabel 3, bahwa variabel komponen utama ke 1 yang disetarakan dengan penciri ukuran jantan, betina dan hasil koreksi betina ke jantan pada sapi Bali memiliki keragaman total secara berurutan $70,3 \%, 78,1 \%$ dan $78,1 \%$. Sapi Simbal jantan, betina dan koreksi betina ke jantan memiliki keragaman total secara berurutan $86 \%, 92,6 \%$ dan $96,2 \%$. Persentase ini merupakan proporsi keragaman terbesar diantara komponen-komponen utama yang diperoleh. Vektor eigen tertingi yang diperoleh pada persamaan ukuran jantan, betina dan hasil koreksi betina ke jantan pada sapi Bali dan sapi Simbal adalah lingkar dada. Hasil ini menunjukkan bahwa lingkar dada dapat dijadikan sebagai penciri ukuran karena memiliki kontribusi terbesar terhadap persamaan ukuran. Menurut Hikmawaty et al. (2014) bahwa lingkar dada adalah salah satu ukuran tubuh yang berkorelasi positif dengan skor ukuran tubuh.

Tabel 3. Penciri ukuran dan bentuk tubuh sapi Bali dan sapi Simbal

\begin{tabular}{|c|c|c|c|c|}
\hline Uraian & & Persamaan & $\mathrm{KT}(\%)$ & $\Lambda$ \\
\hline \multirow{2}{*}{ Jantan Bali } & Ukuran Tubuh & $\begin{array}{l}0,335 \mathrm{~PB}+0,316 \mathrm{TP}+\mathbf{0 , 4 1 6} \mathbf{L D}+0,404 \mathrm{DaD}+0,396 \\
\mathrm{LeD}+0,370 \mathrm{LK}+0,398 \mathrm{Tpi}\end{array}$ & 70,3 & 4,922 \\
\hline & Bentuk Tubuh & $\begin{array}{l}-0,697 \text { PB + 0,405 TP }-0,229 \mathrm{LD}-0,217 \mathrm{DaD}+0,291 \\
\mathrm{LeD}+0,403 \mathrm{LK}+0,059 \mathrm{Tpi}\end{array}$ & 10,3 & 0,718 \\
\hline \multirow{2}{*}{ Betina Bali } & Ukuran Tubuh & $\begin{array}{l}0,369 \mathrm{~PB}+0,355 \mathrm{TP}+\mathbf{0 , 4 0 7} \mathbf{L D}+0,386 \mathrm{DaD}+0,371 \\
\mathrm{LeD}+0,367 \mathrm{LK}+0,389 \mathrm{Tpi}\end{array}$ & 78,1 & 5,464 \\
\hline & Bentuk Tubuh & $\begin{array}{l}-0,393 \text { PB + 0,689 TP }-0,159 \text { LD }-0,204 \text { DaD - 0,291 } \\
\text { LeD + 0,465 LK - 0,047 Tpi }\end{array}$ & 6,4 & 0,446 \\
\hline \multirow{2}{*}{$\begin{array}{c}\text { Koreksi } \\
\text { betina ke } \\
\text { jantan Bali }\end{array}$} & Ukuran Tubuh & $\begin{array}{l}0,369 \mathrm{~PB}+0,355 \mathrm{TP}+\mathbf{0 , 4 0 7} \mathbf{L D}+0,386 \mathrm{DaD}+0,371 \\
\mathrm{LeD}+0,367 \mathrm{LK}+0,389 \mathrm{Tpi}\end{array}$ & 78,1 & 5,464 \\
\hline & Bentuk Tubuh & $\begin{array}{l}-0,393 \text { PB + 0,689 TP }-0,159 \text { LD - 0,204 DaD - 0,291 } \\
\text { LeD + 0,465 LK - 0,047 Tpi }\end{array}$ & 6,4 & 0,446 \\
\hline \multirow{2}{*}{$\begin{array}{l}\text { Jantan } \\
\text { Simbal }\end{array}$} & Ukuran Tubuh & $\begin{array}{l}0,387 \mathrm{~PB}+0,358 \mathrm{TP}+\mathbf{0 , 3 9 8} \mathbf{L D}+0,359 \mathrm{DaD}+0,384 \\
\mathrm{LeD}+0,376 \mathrm{LK}+0,380 \mathrm{Tpi}\end{array}$ & 86 & 6,021 \\
\hline & Bentuk Tubuh & $\begin{array}{l}0,268 \mathrm{~PB}+\mathbf{0 , 6 8 8} \mathbf{T P}+0,050 \mathrm{LD}-0,558 \mathrm{DaD}-0,130 \\
\mathrm{LeD}-0,352 \mathrm{LK}+0,034 \mathrm{Tpi}\end{array}$ & 4,8 & 0,333 \\
\hline \multirow{2}{*}{$\begin{array}{l}\text { Betina } \\
\text { Simbal }\end{array}$} & Ukuran Tubuh & $\begin{array}{l}0,384 \mathrm{~PB}+0,356 \mathrm{TP}+\mathbf{0 , 3 8 8} \mathbf{L D}+0,374 \mathrm{DaD}+0,378 \\
\mathrm{LeD}+0,382 \mathrm{LK}+0,383 \mathrm{Tpi}\end{array}$ & 92,6 & 6,485 \\
\hline & Bentuk Tubuh & $\begin{array}{l}-0,203 \mathrm{~PB}+\mathbf{0 , 7 8 1} \mathbf{T P}-0,085 \mathrm{LD}-0,499 \mathrm{DaD}+0,126 \\
\mathrm{LeD}-0,229 \mathrm{LK}+0,156 \mathrm{Tpi}\end{array}$ & 3,8 & 0,265 \\
\hline \multirow{2}{*}{$\begin{array}{l}\text { koreksi } \\
\text { betina ke } \\
\text { jantan } \\
\text { Simbal }\end{array}$} & Ukuran Tubuh & $\begin{array}{l}0,384 \mathrm{~PB}+0,356 \mathrm{TP}+\mathbf{0 , 3 8 8} \mathbf{L D}+0,374 \mathrm{DaD}+0,378 \\
\mathrm{LeD}+0,382 \mathrm{LK}+0,383 \mathrm{Tpi}\end{array}$ & 92,6 & 6,485 \\
\hline & Bentuk Tubuh & $\begin{array}{l}-0,203 \mathrm{~PB}+\mathbf{0 , 7 8 1} \mathbf{T P}-0,085 \mathrm{LD}-0,499 \mathrm{DaD}+0,126 \\
\mathrm{LeD}-0,229 \mathrm{LK}+0,156 \mathrm{Tpi}\end{array}$ & 3,8 & 0,265 \\
\hline
\end{tabular}

Keterangan $: \mathrm{PB}$ = Panjang Badan, TP = Tinggi Pundak, LD = Lingkar Dada, DaD = Dalam Dada, LeD = Lebar Dada, LK = Lingkar Kanon, TPi = Tinggi Pinggul.

Variabel komponen utama ke-2 tertinggi yang diperoleh dalam persamaan bentuk tubuh sapi Bali dan sapi Simbal adalah tinggi pundak, artinya setiap peningkatan tinggi pundak baik pada sapi Bali maupun sapi Simbal akan berpengaruh terhadap peningkatan skor bentuk 
begitupun sebaliknya. Menurut Hikmawaty et al. (2014) penciri bentuk pada sapi Bali jantan BPTHMT Serading Kabupaten Sumbawa adalah tinggi pundak. Sehingga dapat diketahui bahwa lingkar dada merupakan penciri ukuran pada sapi Bali dan sapi Simbal. Sedangkan tinggi pundak merupakan penciri bentuk pada sapi Bali dan sapi Simbal.

REGRESI UKURAN-UKURAN TUBUH DENGAN BOBOT BADAN SAPI BALI DAN SAPI SIMBAL
Uji analisis regresi menunjukkan hasil bahwa ukuran-ukuran tubuh sapi Bali dan sapi Simbal berpengaruh nyata $(\mathrm{P}<0,05)$ terhadap bobot badan. Artinya terdapat hubungan antara ukuran-ukuran tubuh dengan bobot badan. Bobot badan dipengaruhi oleh besar kecilnya ukuran-ukuran tubuh. Persamaan regresi ukuran-ukuran tubuh dengan bobot badan sapi Bali dan sapi Simbal dapat dilihat pada Tabel 4 dan Tabel 5.

Tabel 4. Persamaan regresi ukuran-ukuran tubuh dengan bobot badan sapi Bali

\begin{tabular}{|c|c|c|}
\hline Uraian & Variabel & Persamaan \\
\hline \multirow{8}{*}{ Jantan } & Umum & $\begin{aligned} \mathrm{BB}= & -601,4+0,091 \mathrm{~PB}-0,352 \mathrm{TP}+4,550 \mathrm{LD}-0,672 \mathrm{DaD}+2,49 \mathrm{LeD} \\
& +8,92 \mathrm{LK}+0,129 \mathrm{Tpi}\end{aligned}$ \\
\hline & BB-PB & $\mathrm{BB}=-483+6,08 \mathrm{~PB}$ \\
\hline & BB-TP & $\mathrm{BB}=-351+5,32 \mathrm{TP}$ \\
\hline & BB-LD & $\mathrm{BB}=-553,8+5,395 \mathrm{LD}$ \\
\hline & BB-DaD & $\mathrm{BB}=-79,9+6,256 \mathrm{DaD}$ \\
\hline & BB-LeD & $\mathrm{BB}=-300,5+15,19 \mathrm{LeD}$ \\
\hline & BB-LK & $\mathrm{BB}=-354,2+39,45 \mathrm{LK}$ \\
\hline & BB-Tpi & $\mathrm{BB}=-413,5+5,626 \mathrm{Tpi}$ \\
\hline \multirow{8}{*}{ Betina } & Umum & $\begin{aligned} \mathrm{BB}= & -440,3+0,491 \mathrm{~PB}+0,436 \mathrm{TP}+3,376 \mathrm{LD}-0,161 \mathrm{DaD}+0,051 \mathrm{LeD} \\
& +3,96 \mathrm{LK}+0,380 \mathrm{Tpi}\end{aligned}$ \\
\hline & BB-PB & $\mathrm{BB}=-504.7+6.540 \mathrm{~PB}$ \\
\hline & BB-TP & $\mathrm{BB}=-339,4+5,043 \mathrm{TP}$ \\
\hline & BB-LD & $\mathrm{BB}=-389,4+4,411 \mathrm{LD}$ \\
\hline & BB-DaD & $\mathrm{BB}=-150,7+7,611 \mathrm{DaD}$ \\
\hline & BB-LeD & $\mathrm{BB}=-100,5+9,28 \mathrm{LeD}$ \\
\hline & BB-LK & $\mathrm{BB}=-219,8+29,64 \mathrm{LK}$ \\
\hline & BB-Tpi & $\mathrm{BB}=-357,2+5,075 \mathrm{TPi}$ \\
\hline \multirow{8}{*}{$\begin{array}{c}\text { Koreksi } \\
\text { betina ke } \\
\text { jantan }\end{array}$} & Umum & $\begin{aligned} \mathrm{BB}= & -503,0+0,519 \mathrm{~PB}+0,490 \mathrm{TP}+3,537 \mathrm{LD}-0,176 \mathrm{DaD}+0,053 \mathrm{LeD} \\
& +4,30 \mathrm{LK}+0,418 \mathrm{TPi}\end{aligned}$ \\
\hline & BB-PB & $\mathrm{BB}=-557+6.908 \mathrm{~PB}$ \\
\hline & BB-TP & $\mathrm{BB}=-387,7+5,667 \mathrm{TP}$ \\
\hline & BB-LD & $\mathrm{BB}=-444,8+4,621 \mathrm{LD}$ \\
\hline & BB-DaD & $\mathrm{BB}=-172,2+8,277 \mathrm{DaD}$ \\
\hline & BB-LeD & $\mathrm{BB}=-114,8+9,62 \mathrm{LeD}$ \\
\hline & BB-LK & $\mathrm{BB}=-251,1+32,18 \mathrm{LK}$ \\
\hline & BB-Tpi & $\mathrm{BB}=-408+5,576 \mathrm{Tpi}$ \\
\hline
\end{tabular}

Keterangan $: \mathrm{BB}=$ Bobot Badan, $\mathrm{PB}=$ Panjang Badan, $\mathrm{TP}=$ Tinggi Pundak, $\mathrm{LD}=$ Lingkar Dada, $\mathrm{DaD}=$ Dalam Dada, LeD = Lebar Dada, LK = Lingkar Kanon, TPi = Tinggi Pinggul.

Tabel 4. menunjukkan bahwa persamaan regresi secara umum pada sapi Bali jantan, betina dan koreksi betina ke jantan secara berurutan adalah $\mathrm{BB}=-601,4+0,091 \mathrm{~PB}$ $-0,352 \mathrm{TP} \quad+4,550 \mathrm{LD} \quad-0,672 \mathrm{DaD}$ $+2,49 \mathrm{LeD}+8,92 \mathrm{LK}+0,129 \mathrm{Tpi}, \mathrm{BB}=-$ $440,3+0,491 \mathrm{~PB}+0,436 \mathrm{TP}+3,376 \mathrm{LD}$ $-0,161 \mathrm{DaD}+0,051 \mathrm{LeD}+3,96 \mathrm{LK}$ $+0,380$ Tpi dan $\mathrm{BB}=-503,0+0,519 \mathrm{~PB}$ $+0,490 \mathrm{TP} \quad+3,537 \mathrm{LD} \quad-0,176 \mathrm{DaD}$ + 0,053 LeD + 4,30 LK + 0,418 Tpi. Nilai koefisien regresi dari masing-masing ukuran tubuh menunjukkan angka kenaikan bobot badan yang disebabkan oleh kenaikan setiap 1 cm ukuran-ukuran tubuh tersebut. Persamaan regresi secara parsial pada lingkar dada sapi Bali jantan, betina dan koreksi betina ke jantan adalah $\mathrm{BB}=-553,8+5,395 \mathrm{LD}, \mathrm{BB}=-389,4$ $+4,411 \mathrm{LD}$ dan $\mathrm{BB}=-444,8+4,621 \mathrm{LD}$. Berdasarkan persamaan tersebut diketahui 
bahwa setiap penambahan $1 \mathrm{~cm}$ lingkar dada sapi Bali jantan diikuti kenaikan bobot badan sebesar $5,395 \mathrm{~kg}$, setiap penambahan $1 \mathrm{~cm}$ lingkar dada sapi Bali betina diikuti kenaikan bobot badan sebesar $4,411 \mathrm{~kg}$ dan setiap penambahan $1 \mathrm{~cm}$ lingkar dada pada koreksi betina ke jantan jantan diikuti kenaikan bobot badan sebesar $4,621 \mathrm{~kg}$. menurut Zafitra et al. (2020) bahwa kenaikan ukuran-ukuran tubuh sebesar $1 \mathrm{~cm}$ akan mengakibatkan kenaikan bobot badan sesuai dengan sesuai dengan nilai koefsiennya.

Tabel 5. Persamaan regresi ukuran-ukuran tubuh dengan bobot badan sapi Simbal

\begin{tabular}{|c|c|c|}
\hline Uraian & Variabel & Persamaan \\
\hline \multirow{8}{*}{ Jantan } & Umum & $\begin{aligned} \mathrm{BB}= & -221,5-0,733 \mathrm{~PB}+0,358 \mathrm{TP}+3,857 \mathrm{LD}+1,230 \mathrm{DaD}+0,86 \mathrm{LeD}-2,48 \mathrm{LK} \\
& -0,231 \mathrm{Tpi}\end{aligned}$ \\
\hline & $\mathrm{BB}-\mathrm{PB}$ & $\mathrm{BB}=-186,8+4,107 \mathrm{~PB}$ \\
\hline & BB-TP & $\mathrm{BB}=-261,7+5,017 \mathrm{TP}$ \\
\hline & BB-LD & $\mathrm{BB}=-274,8+3,990 \mathrm{LD}$ \\
\hline & BB-DaD & $\mathrm{BB}=16,3+6,843 \mathrm{DaD}$ \\
\hline & BB-LeD & $\mathrm{BB}=55,0+7,098 \mathrm{LeD}$ \\
\hline & BB-LK & $\mathrm{BB}=-162,7+27,02 \mathrm{LK}$ \\
\hline & BB-Tpi & $\mathrm{BB}=-452,8+6,342 \mathrm{Tpi}$ \\
\hline \multirow{8}{*}{ Betina } & Umum & $\begin{aligned} \mathrm{BB}= & -557,9-3,22 \mathrm{~PB}-0,446 \mathrm{TP}+5,81 \mathrm{LD}+1,80 \mathrm{DaD}+0,71 \mathrm{LeD}+6,26 \mathrm{LK} \\
& +1,79 \mathrm{Tpi}\end{aligned}$ \\
\hline & $\mathrm{BB}-\mathrm{PB}$ & $\mathrm{BB}=-196,5+4,162 \mathrm{~PB}$ \\
\hline & BB-TP & $\mathrm{BB}=-454,9+6,587 \mathrm{TP}$ \\
\hline & BB-LD & $\mathrm{BB}=-499,7+5,342 \mathrm{LD}$ \\
\hline & BB-DaD & $\mathrm{BB}=-89,9+8,987 \mathrm{DaD}$ \\
\hline & BB-LeD & $\mathrm{BB}=-207,3+13,73 \mathrm{LeD}$ \\
\hline & BB-LK & $\mathrm{BB}=-122,2+25,46 \mathrm{LK}$ \\
\hline & BB-Tpi & $\mathrm{BB}=-578,1+7,298 \mathrm{Tpi}$ \\
\hline \multirow{8}{*}{$\begin{array}{c}\text { Koreksi } \\
\text { betina ke } \\
\text { jantan }\end{array}$} & Umum & $\begin{array}{l}\mathrm{BB}=-598,1-3,31 \mathrm{~PB}-0,462 \mathrm{TP}+6,11 \mathrm{LD}+1,82 \mathrm{DaD}+0,69 \mathrm{LeD}+6,24 \mathrm{LK}+1,87 \\
\text { Tpi }\end{array}$ \\
\hline & $\mathrm{BB}-\mathrm{PB}$ & $\mathrm{BB}=-210,6+4,284 \mathrm{~PB}$ \\
\hline & BB-TP & $\mathrm{BB}=-488+6,826 \mathrm{TP}$ \\
\hline & BB-LD & $\mathrm{BB}=-535,7+5,617 \mathrm{LD}$ \\
\hline & BB-DaD & $\mathrm{BB}=-96,4+9,053 \mathrm{DaD}$ \\
\hline & BB-LeD & $\mathrm{BB}=-222,2+13,44 \mathrm{LeD}$ \\
\hline & BB-LK & $\mathrm{BB}=-131,0+25,40 \mathrm{LK}$ \\
\hline & BB-Tpi & $\mathrm{BB}=-619,8+7,636 \mathrm{Tpi}$ \\
\hline
\end{tabular}

Keterangan $: \mathrm{BB}=$ Bobot Badan, $\mathrm{PB}=$ Panjang Badan, $\mathrm{TP}=$ Tinggi Pundak, $\mathrm{LD}=$ Lingkar Dada, $\mathrm{DaD}=$ Dalam Dada, LeD = Lebar Dada, LK = Lingkar Kanon, TPi = Tinggi Pinggul.

Tabel 5. menunjukkan bahwa persamaan regresi secara umum pada sapi Simbal jantan, betina dan koreksi betina ke jantan secara berurutan adalah $\mathrm{BB}=-221,5-0,733 \mathrm{~PB}$ $+0,358 \mathrm{TP}+3,857 \mathrm{LD}+1,230 \mathrm{DaD}$ $+0,86 \mathrm{LeD}-2,48 \mathrm{LK}-0,231 \mathrm{Tpi}, \mathrm{BB}=-557,9$ $-3,22 \mathrm{~PB}-0,446 \mathrm{TP}+5,81 \mathrm{LD}+1,80 \mathrm{DaD}$ $+0,71 \mathrm{LeD}+6,26 \mathrm{LK}+1,79 \mathrm{Tpi}$ dan $\mathrm{BB}=-$ $598,1-3,31 \mathrm{~PB} \quad-0,462 \mathrm{TP} \quad+6,11 \mathrm{LD}$ + 1,82 DaD + 0,69 LeD + 6,24 LK + 1,87 Tpi. Persamaan regresi secara parsial pada lingkar dada sapi Simbal jantan, betina dan koreksi betina ke jantan adalah $\mathrm{BB}=-274,8$ $+3,990 \mathrm{LD}, \mathrm{BB}=-499,7+5,342 \mathrm{LD}$ dan $\mathrm{BB}=$ $-535,7+5,617$ LD. Berdasarkan persamaan tersebut diketahui bahwa setiap penambahan 1 cm lingkar dada sapi Simbal jantan diikuti kenaikan bobot badan sebesar 5,95 kg, setiap penambahan $1 \mathrm{~cm}$ lingkar dada sapi Simbal betina diikuti kenaikan bobot badan sebesar 5, $342 \mathrm{~kg}$ dan setiap penambahan $1 \mathrm{~cm}$ lingkar dada pada koreksi betina ke jantan jantan diikuti kenaikan bobot badan sebesar 5,617 kg. Menurut Ikhsanuddin et al. (2018) bahwa ukuran-ukuran tubuh yang mengalami peningkatan sebesar $1 \mathrm{~cm}$ akan terjadi kenaikan bobot badan sesuai dengan koefisiennya. 
KORELASI DAN DETERMINASI UKURAN - UKURAN TUBUH DENGAN BOBOT BADAN SAPI BALI DAN SAPI SIMBAL
Korelasi dan determinasi antara ukuranukuran tubuh dengan bobot badan pada sapi Bali dan sapi Simbal dapat dilihat pada Tabel 6.

Tabel 6. Korelasi dan determinasi ukuran-ukuran tubuh dengan bobot badan sapi Bali

\begin{tabular}{|c|c|c|c|c|c|c|c|}
\hline \multirow[t]{2}{*}{ Uraian } & \multirow[t]{2}{*}{ Variabel } & \multicolumn{2}{|c|}{ Jantan } & \multicolumn{2}{|c|}{ Betina } & \multicolumn{2}{|c|}{$\begin{array}{c}\text { Koreksi betina ke } \\
\text { jantan }\end{array}$} \\
\hline & & $\mathrm{r}$ & $\mathrm{r}^{2}$ & $\mathrm{r}$ & $\mathrm{r}^{2}$ & $\mathrm{r}$ & $r^{2}$ \\
\hline \multirow{8}{*}{$\begin{array}{l}\text { Sapi } \\
\text { Bali }\end{array}$} & Umum & 0,985 & 0,970 & 0,993 & 0,987 & 0,993 & 0,987 \\
\hline & Panjang Badan VS BB & 0,734 & 0,539 & 0,828 & 0,686 & 0,828 & 0,686 \\
\hline & Tinggi Pundak VS BB & 0,607 & 0,368 & 0,774 & 0,599 & 0,774 & 0,599 \\
\hline & Lingkar Dada VS BB & 0,969 & 0,939 & 0,986 & 0,972 & 0,986 & 0,972 \\
\hline & Dalam Dada VS BB & 0,786 & 0,618 & 0,843 & 0,711 & 0,843 & 0,711 \\
\hline & Lebar Dada VS BB & 0,815 & 0,664 & 0,845 & 0,714 & 0,845 & 0,714 \\
\hline & Tinggi Pinggul VS BB & 0,782 & 0,612 & 0,832 & 0,692 & 0,832 & 0,692 \\
\hline & Lingkar Kanon VS BB & 0,776 & 0,602 & 0,881 & 0,776 & 0,881 & 0,776 \\
\hline \multirow{8}{*}{$\begin{array}{l}\text { Sapi } \\
\text { Simbal }\end{array}$} & Umum & 0,979 & 0,958 & 0,976 & 0,953 & 0,976 & 0,953 \\
\hline & Panjang Badan VS BB & 0,894 & 0,799 & 0,923 & 0,852 & 0,923 & 0,852 \\
\hline & Tinggi Pundak VS BB & 0,815 & 0,664 & 0,841 & 0,707 & 0,841 & 0,707 \\
\hline & Lingkar Dada VS BB & 0,973 & 0,947 & 0,964 & 0,929 & 0,964 & 0,929 \\
\hline & Dalam Dada VS BB & 0,840 & 0,706 & 0,919 & 0,845 & 0,919 & 0,845 \\
\hline & Lebar Dada VS BB & 0,937 & 0,878 & 0,918 & 0,843 & 0,918 & 0,843 \\
\hline & Tinggi Pinggul VS BB & 0,848 & 0,719 & 0,939 & 0,882 & 0,939 & 0,882 \\
\hline & Lingkar Kanon VS BB & 0,834 & 0,696 & 0,943 & 0,889 & 0,943 & 0,889 \\
\hline
\end{tabular}

Keterangan : $\mathrm{BB}=$ Bobot Badan, $\mathrm{r}=$ Korelasi, $\mathrm{r}^{2}=$ Determinasi.

Nilai determinasi (r2) pada Tabel 6 . menunjukkan bahwa $97 \%$ bobot badan jantan, 98,7\% bobot badan betina dan $98,7 \%$ bobot badan koreksi betina ke jantan pada sapi Bali ditentukan oleh ukuran-ukuran tubuh sedangkan sisanya disebabkan oleh faktor lain yang tidak teramati, sedangkan pada sapi Simbal 95,8\% bobot badan jantan, 95,3\% bobot badan betina dan $95,3 \%$ bobot badan koreksi betina ke jantan ditentukan oleh ukuran-ukuran tubuh sedangkan sisanya dipengaruhi oleh faktor lain yang tidak teramati.

Lingkar dada (LD) menunjukkan nilai korelasi tertinggi antara ukuran-ukuran tubuh dengan bobot badan baik pada sapi bali maupun sapi Simbal sehingga dapat dijadikan dasar untuk mengestimasi bobot badan sapi Bali dan sapi Simbal. Menurut Ni'am et al. (2012) bahwa pada umur yang sama lingkar dada mempunyai korelasi lebih tinggi terhadap bobot badan daripada lebar dada, panjang badan dan tinggi pundak. Lingkar dada memiliki keeratan hubungan terhadap bobot badan diduga karena lingkar dada merupakan ukuran tubuh terbesar jika dibandingkan dengan ukuran-ukuran tubuh lainnya sehingga sebagian besar bobot badan terdapat pada lingkar dada. Menurut Aguantara et al. (2019) bahwa lingkar dada menjadi korelasi tertinggi karena berhubungan langsung dengan dada dan ruang abdomen dimana sebagian besar bobot badan ternak berasal dari bagian dada hingga pinggul.

\section{KESIMPULAN}

Bobot badan, Pertambahan bobot badan serta ukuran-ukuran tubuh sapi Bali lebih rendah dibandingkan sapi Simbal. Penciri ukuran sapi Bali dan sapi Simbal adalah lingkar dada (LD) sedangkan penciri bentuk sapi Bali dan sapi Simbal adalah tinggi pundak (TP). Ukuran tubuh yang memiliki korelasi tertinggi terhadap bobot badan pada sapi Bali dan sapi Simbal adalah lingkar dada (LD).

\section{DAFTAR PUSTAKA}

Aguantara F, T Rozi dan Maskur. 2019. Karakteristik morfometrik (ukuran linier dan lingkar tubuh) sapi persilangan Sumbawa x Bali (Sumbal) yang dipelihara secara semi intensif di Kabupaten Sumbawa. Jurnal Ilmu Dan Teknologi Peternakan Indonesia, 5(1), hal. 17-26. doi:10.29303/jitpi.v5i1.54. 
Alhamda, S. 2016. Buku Ajar Metlit dan Statistik. Deepublish. Yogyakarta.

Baaka A, Murwanto AG dan Lumatauw S. 2013. Seleksi berat badan sapi Bali umur satu tahun dengan menggunakan program simulasi genup. Jurnal Ilmu Peternakan. 4(2): 83- 92.

Depison. 2010. Performans anak hasil persilangan induk sapi Bali dengan beberapa bangsa pejantan di Kabupaten Batanghari Provinsi Jambi. Agripet, 10(1), hal. 37-41.

Gaspersz V. 2006. "Teknik Analisis Dalam Penelitian Percobaan," Tarsito. Bandung.

Gunawan A, K Jamal dan Sumantri C. 2008. Pendugaan bobot badan melalui analisis morfometrik dengan pendekatan regresi terbaik best-subset pada domba Garut tipe pedaging, tangkas dan persilangannya. Majalah Ilmu Peternakan, 11(1), hal. 1-6.

Hamdani MDI, Adhianto K, Sulastri, Husni A dan Renitasari. 2017. Ukuran-ukuran tubuh sapi Krui jantan dan betina di Kabupaten Pesisir Barat Lampung. Jurnal Ilmu ternak, 17(2), hal. 97-102. doi: 10.24198/jit.v17i1.16068.

Hartati, Sumadi, Subandriyo dan Hartatik T. 2010. Keragaman morfologi dan diferensiasi genetik sapi Peranakan Ongole di peternakan rakyat. Jurnal Ilmiah Ternak Veteriner, 15(1), hal. 72-80.

Hikmawaty, Gunawan A, Noor R dan Jakaria. 2014. Identifikasi ukuran tubuh dan bentuk tubuh sapi Bali di beberapa pusat pembibitan melalui pendekatan Analisis komponen utama. Jurnal Ilmu Produksi Dan Teknologi Hasil Peternakan, 2(1), hal. 231-237.

Ikhsanuddin, V Margareta, A Nurgiartinigsih, Kuswati dan Zainuddin. 2018. Korelasi ukuran tubuh terhadap bobot badan sapi Aceh umur sapih dan umur satu tahun. Agripet, 18(2), hal. 117-122. doi: 10.17969/agripet.v18i2.12355.

Khairi F. 2016. Evaluasi produksi dan kualitas semen sapi Simmental terhadap tingkat bobot badan berbeda,.Jurnal Peternakan, 13(2), hal. 54-58.

Kocu N, R Priyanto, Salundik dan Jakaria. 2019. Produktivitas sapi Bali betina dan hasil persilangannya dengan Limousin dan Simmental yang di pelihara berbasis pakan hijauan di kabupaten Keerom Papua. Jurnal Ilmu Produksi dan Teknologi Hasil Peternakan, 7(1), hal. 29-34.

Ni'am HUM, A Purnomoadi dan S Dartosukarno. 2012. Hubungan antara ukuran-ukuran tubuh dengan bobot badan sapi Bali betina pada berbagai kelompok umur. Animal Agriculture Journal, 1(1), hal. 541-556.

Putra WPB, Sumadi and Hartatik T. 2014. The estimation of body weight of Aceh cattle using some measurements of body dimension. JITP, 3(2), hal. 76-80.

Rachma Sri AB, H Harada and Ishida. 2011. The estimation of growth curve of Bali cattle at bone and barru districts, South Sulawesi, Indonesia using ten body measurements. Journal of the Indonesian Tropical Animal Agriculture, 36(4), hal. 228-236. doi: 10.14710/jitaa.36.4.228-236.

Setiyono, AHA Kusuma dan Rusman. 2017. Pengaruh bangsa, umur, jenis kelamin terhadap kualitas daging sapi potong di Daerah Istimewa Yogyakarta. Buletin Peternakan, 41(2), hal. 176-186. doi: 10.21059/buletinpeternak.v41i2.9935

Socheh M, SW Purbojo dan LR Hakim. 2018. Pengaruh bangsa sapi potong terhadap bobot potong, bobot karkas, dan persentase karkas. Prosiding Seminar Teknologi dan Agribisnis Peternakan VI. Fakultas Peternakan Jenderal Soedirman.

Susanti I, MN Ihsan dan Sri Wahjuningsih. 2015. Pengaruh bangsa pejantan terhadap pertumbuhan pedet hasil IB di wilayah Kecamatan Bantur Kabupaten Malang. Jurnal Ternak Tropika, 16(1), hal. 41-47. doi 10.21776/ub.jtapro.2015.16.01.7.

Syaiful FL, Khasrad dan S Maulida. 2020. Identifikasi ukuran tubuh sapi Bali dan simbal (simmental-Bali) di kecamatan Luhak Nan Duo Kabupaten Pasaman Barat. Jurnal sain peternakan, 15(2), hal. 219-226. doi:10.31186/jspi.id.15.2.219226.

Zafitra A, Gushairiyanto, $\mathrm{H}$ Ediyanto dan Depison. 2020. Karakterisasi morfometrik dan bobot badan pada sapi bali dan simbal di kecamatan Bangko kabupaten Merangin. Majalah Ilmiah Peternakan, 23(2), hal. 66-72. 